УДК 656.027

\title{
РОЗВИТОК ВИСОКОШВИДКІСНОГО РУХУ В УКРАЇНІ НА ОСНОВІ ФОРМУВАННЯ ВИРОБНИЧО-ЛОГІСТИЧНИХ КЛАСТЕРІВ
}

Д-р екон. наук В.Л. Дикань, канд. екон. наук М.В. Корінь

\section{РАЗВИТИЕ ВЫСОКОСКОРОСТНОГО ДВИЖЕНИЯ В УКРАИНЕ НА ОСНОВЕ ФОРМИРОВАНИЯ ПРОИЗВОДСТВЕННО-ЛОГИСТИЧЕСКИХ КЛАСТЕРОВ}

Д-р экон. наук В.Л. Дикань, канд. экон. наук М.В. Коринь

\section{DEVELOPMENT IN UKRAINE HIGH SPEED FORMATION BASED INDUSTRIAL CLUSTERS AND LOGISTICS}

Doct. of econ. sciences V. Dykan, cand. of econ. sciences M. Korin

У статті визначено, щь розвиток високошвидкісного руху в Україні є масштабною програмою технологічної модернізаиії інфраструктури залізниць, щзо пов'язана з освоєнням новітніх технологій будівництва та якісно новою організацією процесів транспортування пасажсирів $i$ вантажів. Встановлено негативні фактори, що стримують організацію високошвидкісного руху на залізнииях країни. Запропоновано застосування специфічного підходу до розбудови високошвидкісних залізничних магістралей, заснованого на взаємозалежності та взаємообумовленості розвитку виробничого та логістичного комплексу країни, основною формою взаємодії яких має стати виробничо-логістичний кластер.

Ключові слова: розвиток, високочвидкісний рух, залізничний транспорт, виробничологістичний кластер, фактори.

В статье определено, что развитие высокоскоростного движения в Украине выступает масштабной программой модернизации инфраструктуры железных дорог, связанной с освоением новейших технологий строчтельства и организации процессов транспортировки пассажиров и грузов. Установлены негативные факторы, сдерживающие организачию высокоскоростного движения на железных дорогах страны. Предложено применение специфического подхода к развитию высокоскоростных железнодорожных магистралей, основанного на взаимозависимости и взаимообусловленности развития производственного и логистического комплекса страны, основной формой взаимодействия которых должен стать производственно-логистический кластер.

Ключевые слова: развитие, высокоскоростное движение, железнодорожный транспорт, производственно-логистический кластер, факторы.

The article stipulates that the development of high-speed movement in Ukraine is a large-scale program of technological modernization of the railway infrastructure that is connected with the development of new technologies and organization building processes transporting passengers and cargo. Grounded negative factors that hinder the organization of high-speed railways in the country. The specific operating conditions Ukrainian railways which prevent the organization of high-speed railways in the country identified: the presence of mixed trains, much larger volumes of transport work, increased axial loading of the rolling stock and the intense movement of trains. An application specific approach to building high-speed rail lines, based on interdependence and interdependence of production and logistics systems of the country. The main form of interaction of these complexes defined industrial and logistics cluster, as modern forms of enterprise integration, which involves the pooling of resources, capabilities and competencies to achieve a common strategic goal - ensuring the implementation of development projects of high-speed rail traffic in the country. The basic provisions creating industrial and logistics clusters in terms of ensuring the development of high-speed movement in Ukraine.

Keywords: development, high traffic, rail, industrial and logistics cluster, factors. 
Вступ. Економічне майбутне України в значній мірі залежить від рівня використання ii транзитного й інтелектуального потенціалів, реалізації масштабних проектів розвитку транспортної системи країни. Адже в умовах формування єдиного світового транспортного простору та інтенсифікації товаротранспортних потоків у напрямку Європа-Азія саме вигідне географічне положення нашої держави та проходження іiі територією Пан'європейських МТК служить основою для інтенсифікації не тільки обсягів перевезення транзитних вантажів, але й збільшення пасажиропотоку через країну.

Однак, за існуючого стану інфраструктури залізничного транспорту та невідповідності якості транспортних послуг встановленим європейським стандартам остаточно не втратити статус транзитної держави та підвищити конкурентоспроможність залізничної галузі на європейському транспортному ринку допоможе реалізація проектів розвитку високошвидкісного залізничного руху в Україні як масштабної програми технологічної модернізації інфраструктури 3 освоєнням новітніх технологій будівництва і організації процесів транспортування пасажирів і вантажів.

Аналіз останніх досліджень та публікацій довів достатню актуальність вирішення проблем розвитку високошвидкісного руху в Україні. Зокрема, розробці концептуальних положень розвитку високошвидкісного залізничного сполучення в країні присвячено праці Альошинського С.С., Бараша Ю.С., Богомолової Н.I., Бутько Т.В., Кірдіної О.Г., Момот А.В., Пащенка Ю.С. та ін. [1-6]. Ці вчені доводять, що саме впровадження високошвидкісного залізничного сполучення в Україні має вирішальне значення для залучення нашої країни у світові інтеграційні процеси та виступає основним критерієм конкурентоспроможності Укрзалізниці на міжнародному ринку перевезень. Не знижуючи значення попередніх надбань науковців-транспортників, автори статті мають власне бачення вирішення проблеми розвитку високошвидкісного руху в Україні, яке полягає в застосуванні специфічного підходу, заснованого на взаємозалежності та взаємообумовленості розвитку виробничого та логістичного комплексу країни шляхом формування виробничо-логістичних кластерів. Відповідно до цього метою статті $\epsilon$ обгрунтування значення виробничо-логістичних кластерів у забезпеченні реалізації проектів розвитку високошвидкісного руху в Україні.

Основна частина дослідження. Створення швидкісних залізничних магістралей в Україні законодавчо розпочато ще в 2004 році прийняттям Концепції Державної цільової програми впровадження на залізницях швидкісного руху пасажирських поїздів на 2005-2015 роки, якою передбачалося забезпечити швидкісне залізничне сполучення столиці України (м. Київ) 3 великими обласними та промисловими центрами, а також країнами Західної Європи та СНД. Для досягнення даної мети було заплановано реалізацію ряду крупномасштабних заходів, спрямованих як на реконструкцію i модернізацію інфраструктури основних залізничних ліній (будівництво нових залізничних станцій, випрямлення траси руху поїздів зі збільшенням радіусу кривих, модернізація колій, контактної мережі, тягових підстанцій та пристроїв енергопостачання тощо), так і оновлення рухомого складу залізниць шляхом придбання восьми одиниць швидкісних пасажирських поїздів [7].

Аналіз виконання Програми впровадження швидкісного пасажирського руху в Україні дозволив встановити, що іiі реалізація забезпечила часткову адаптацію існуючих об'єктів транспортної інфраструктури до нових вимог споживачів транспортних послуг та сприяла поступовому впровадженню прискореного руху пасажирських поїздів на залізницях України. Нині на залізничних магістралях України курсує 10 прискорених пасажирських поїздів, що рухаються зі швидкістю в 160 км/год, забезпечуючи скорочення тривалості поїздки пасажирів більш ніж на половину.

Однак, поряд 3 великою кількістю переваг від організації курсування прискорених поїздів, більшу привабливість для пасажирів та залізничної галузі мають високошвидкісні залізничні магістралі як з позиції комфортності здійснення поїздки для перших, так і з точки зору завоювання конкурентних переваг та залучення додаткового обсягу пасажиропотоку з боку авіаційного транспорту для залізничного транспорту в цілому. 
Високошвидкісні залізничні магістралі трактуються Міжнародним союзом залізниць (МС3) як стандартні залізничні лінії, до дозволяють здійснювати курсування поїздів зі швидкістю понад 200 км/год по модернізованих залізничних коліях, або нові спеціальні колії, розраховані на швидкість руху понад 250 км/год. Відповідно до цього на сьогоднішній день сформувалася така класифікація швидкісних залізниць для перевезення пасажирів за трьома категоріями максимальної швидкості руху поїздів: перша 200-250 км/год; друга - 250-350 км/год; третя понад 350 км/год [8].

Вивчення тенденцій розвитку залізничного транспорту в світі дозволило встановити, що саме організація високошвидкісного залізничного руху $\epsilon$ найсучаснішою закономірністю розвитку залізниць, що дозволяє забезпечити економію часу та оборотних коштів, скорочення тривалості виробничого циклу (процесу перевезень) та підвищення ефективності роботи транспортної галузі.

Провідними технологіями організації
руху високошвидкісних поїздів на сьогоднішній день володіють Китай і Японія, Франція та Німеччина, Італія, Бельгія, Швейцарія, Угорщина, США, Великобританія, Південна Корея та інші розвинуті країни світу. Швидкість руху поїздів на залізницях цих країн подекуди перевищує 350 км/год, а на окремих ділянках досягає швидкості 486,1 км/год (магістраль Пекін-Шанхай). Активно залучається до проектів будівництва високошвидкісних залізничних магістралей i Росія, керівництво якої бачить головні цілі розвитку високошвидкісних залізничних перевезень у поліпшенні транспортних зв'язків між найбільшими містами та регіонами країни, підвищенні транспортної мобільності населення та якості послуг, які пропонуються пасажирам [9]. 3 грудня 2009 року швидкісний i високошвидкісний рух по модернізованій інфраструктурі з'єднує такі регіони Російської Федерації, як Московська, Тверська, Новгородська, Ленінградська, Володимирська i Нижегородська області. Досить успішно курсують високошвидкісні поїзди «Сапсан» у сполученні Москва - Санкт-Петербург i Москва - Нижній Новгород, «Алегро» - між Санкт-Петербургом і Хельсинки та швидкісні поїзди "Ласточка" - між Санкт-Петербургом i
Великим Новгородом, Москвою і Нижнім Новгородом, розвиваючи швидкість руху до 400 км/год [10].

Саме підвищений інтерес світової спільноти до можливості безперешкодного та швидкого пересування забезпечив реалізацію ряду Програм з будівництва високошвидкісних залізничних ліній. В даний час загальна протяжність високошвидкісних залізничних магістралей у світі складає 7000 км, у тому числі 3750 км в високошвидкісні поїзди обслуговують також полігон протяжністю близько 20 тис. км звичайних залізничних ліній, реконструйованих під швидкісний рух [8].

В Україні ж через відмінні від загальноєвропейських умови експлуатації залізниць, що полягають в наявності змішаного руху поїздів, значно більших обсягах перевізної роботи, підвищених осьових навантаженнях рухомого складу та інтенсивнішому руху поїздів, запровадження високошвидкісного руху й досі залишається лише стратегічним завданням розвитку галузі.

Вивчення тенденцій функціонування залізничного транспорту України дозволило встановити, що розбудова високошвидкісних залізничних магістралей в нашій державі обмежується дією ряду негативних факторів, найвагомішими 3 яких $є$ :

- наявність змішаного руху поїздів, що передбачає курсування по одній і тій самій залізничній колії вантажних та пасажирських поїздів;

- незадовільний стан об’єктів колійної інфраструктури, що проявляється у високому рівні зносу колійного господарства та незадовільному стані залізничного полотна, складності плану та профілю залізничної колії, наявності величезної кількості колій 3 простроченим терміном виконання ремонтних робіт;

- відсутність сучасних технологій виконання колійних робіт та автоматизованих програмних комплексів 3 діагностики колії i моніторингу роботи пересувних засобів;

- низькі темпи оновлення рухомого складу, невідповідність технічних характеристик існуючих його зразків вимогам високошвидкісного руху. На сьогоднішній день рівень фізичного зносу тепловозів складає $95,1 \%$, електровозів - 90,7\%, вантажних вагонів - 88,2 \% [11]. При цьому рухомий склад 
українських залізниць не лише зношений, але й технічно, конструктивно і морально застарілий. Станом на кінець 2013 року більше половини одиниць рухомого складу Укрзалізниці експлуатується понад 15 років і відповідає технічним вимогам 60-70-х років (див. таблицю);

- відсутність вільних фінансових ресурсів та поганий інвестиційний клімат в галузі, нерозвинутість сучасних форм залучення інвестиційних коштів;

- низький рівень державної підтримки проектів розвитку залізничного транспорту;

- високий рівень плинності кадрів та низький рівень продуктивності праці;

- відсутність механізмів міжгалузевої інтеграції, що задовольняли потреби галузі у високих технологіях тощо.

Таблиця

Розподіл рухомого складу залізничного транспорту за роками випуску станом на кінець 2013 року [12]

\begin{tabular}{|l|c|c|c|c|c|c|}
\hline \multirow{2}{*}{ Вид рухомого складу } & \multirow{2}{*}{ Усього } & \multicolumn{5}{|c|}{ у тому числі за роками випуску } \\
\cline { 3 - 7 } & & до 8 років & $9-15$ років & $\begin{array}{c}16-25 \\
\text { років }\end{array}$ & $\begin{array}{c}26-40 \\
\text { років }\end{array}$ & $\begin{array}{c}\text { більше } 40 \\
\text { років }\end{array}$ \\
\hline Тепловози & 100 & 6,7 & 47,7 & 43,1 & 2,5 & - \\
\hline Електровози & 100 & 5 & 2,1 & 18,1 & 24,3 & 50,5 \\
\hline Паровози & 100 & - & - & - & - & 100 \\
\hline Вантажні вагони & 100 & 5,6 & 2,5 & 40,4 & 49,7 & 1,8 \\
\hline Пасажирські вагони & 100 & 5,3 & 2,8 & 24,8 & 14,8 & 52,3 \\
\hline
\end{tabular}

Отже, питання розбудови високошвидкісних залізничних магістралей в Україні $€$ складним, однак стратегічно значимим для реалізації транзитного потенціалу завданням, що вимагає застосування специфічного підходу, заснованого на взаємозалежності та взаємообумовленості розвитку виробничого та логістичного комплексу країни. В аспекті реалізації проектів розвитку високошвидкісного руху в Україні основною формою взаємодії даних комплексів має стати виробничо-логістичний кластер як сучасна форма інтеграції підприємств, що передбачає об'єднання ресурсів, можливостей і компетенцій для досягнення єдиної стратегічної мети - забезпечення реалізації проектів розвитку високошвидкісного залізничного сполучення в країні.

Активізація світових процесів інтеграції підприємств різних галузей економіки i формування на цій основі кластерних структур вказує на неабияку соціально-економічну значимість даної форми партнерства та їх дієвість при реалізації інноваційних перетворень. В цьому аспекті значущою перевагою кластерного підходу $є$ формування ефективного інструментарію розвитку, що забезпечує доступ до інновацій, інформації та знань, робочої сили та постачальників, а також сприяє залученню інвестицій.

Організація високошвидкісного залізничного руху в Україні неможлива без розмежування вантажного i пасажирського руху, а відповідно, потребує: по-перше, будівництва нового залізничного полотна, розрахованого на більш високу пропускну спроможність; по-друге, введення в експлуатацію новітніх зразків рухомого складу i колійної техніки; по-третє, впровадження сучасних технологій управління процесом перевезень і виконання колійних робіт; почетверте, активізації науково-дослідної сфери країни та залучення нових знань у сферу діяльності залізничного комплексу. Саме тому виробничо-логістичні кластери в аспекті реалізації проектів розвитку високошвидкісного руху залізницями України покликані задовольнити потреби галузі в розробці та інноваційних рішеннях, одночасно забезпечивши об'єднання наукового i промислового комплексу 3 транспортною галуззю країни.

Відповідно до цього створення виробничо-логістичних кластерів в аспекті забезпечення розвитку високошвидкісного руху 
в Україні повинно базуватись на таких основних положеннях:

1) основа діяльності кластера має бути інноваційного характеру. Це означає те, що комплекс промислового виробництва повинен задовольняти потреби галузі в інноваціях шляхом розробки новітніх технологій, рухомого складу та нових зразків матеріалів, відповідно стимулюючи власний економічний розвиток;

2) технологічну структуру кластера мають сформувати науково-дослідні інститути та інноваційні центри, промислові підприємства та підприємства металургійного виробництва, що складуть каркас для реалізації інноваційних перетворень на залізничному транспорті країни;

3) основна ідея формування виробничологістичного кластера полягає в тому, щоб на основі науково-обгрунтованих і технологічно реалізованих інноваційних рішень створити умови для інноваційної модернізації залізничної галузі та розвитку високошвидкісного руху в країні;
4) успіх функціонування виробничологістичних кластерів визначається станом бізнес середовища в країні та рівнем державної підтримки через механізми державного регулювання i стимулювання процесів створення кластерних структур або шляхом безпосередньої участі держави в структурі даного кластера.

Висновок. Таким чином, розвиток високошвидкісного руху в Україні $\epsilon$ стратегічним напрямком розвитку не тільки залізничного транспорту, але й в цілому промислового комплексу, який забезпечить активізацію ряду інноваційних перетворень в країні. Формування виробничо-логістичних кластерів має стати тим фундаментом, який створить умови для генерації нових знань i втілення їх результатів у новітні технології для забезпечення інноваційного розвитку залізничної галузі, підвищення конкурентоспроможності Укрзалізниці на міжнародному ринку перевезень.

\section{Список використаних джерел}

1. Альошинський, Є.С. Аналіз можливості організації місцевої роботи на залізничних станціях в умовах впровадження швидкісного пасажирського руху [Текст] / С.С. Альошинський, О.С. Губачова, Г.О. Сіваконева [та ін.] // Східно-Свропейський журнал передових технологій. - 2012. - № 2/3. C. $42-46$.

2. Бараш, Ю. С. Удосконалена методика визначення економічної ефективності будівництва та експлуатації високошвидкісної магістралі в Україні [Текст] / Ю.С. Бараш, А.В. Момот // Наука та прогрес транспорту. Вісник Дніпропетровського національного університету залізничного транспорту ім. ак. В. Лазаряна. - 2013. - Вип. 1(49). - С. 33-50.

3. Богомолова, Н.I. Організаційно-економічні умови та принципи прискорення залізничних перевезень [Текст]: автореф. дис... д-ра економ. наук спец. 08.00.04 «Економіка та управління підприємствами (за видами економічної діяльності)» / Н.І. Богомолова. - К., 2010. - 38 с.

4. Бутько, Т.В. Удосконалення підходів щодо розвитку швидкісного і високошвидкісного руху пасажирських поїздів на залізницях України [Текст] / Т.В. Бутько, Л.О. Пархоменко // Інформаційнокеруючі системи на залізничному транспорті. - 2014. - № 4(Дод.). - С. 14.

5. Кірдіна, О.Г. Концептуальний підхід до створення інтегрованого обєднання «Швидкісні магістралі» [Електронний ресурс]. - Режим доступу: http://www.economy.nayka.com.ua/?op=1\&z=436. - Назва з екрана.

6. Пащенко, Ю.Є. Інтегральна ефективність швидкісних залізничних магістралей [Текст]: монографія / Ю.С. Пащенко, М.Ю. Гончаров, Й.М. Кранц [та ін.]; за ред. С.І. Дорогунцова. - К.: РВПС України НАН України, 2005. - 266 с.

7. Розпорядження Кабінету Міністрів України «Про схвалення Концепції Державної цільової програми впровадження на залізницях швидкісного руху пасажирських поїздів на 2005-2015 роки» [Електронний ресурс]. - Режим доступу: http://zakon1.rada.gov.ua/laws/show/979-2004-\%D1\%80. Назва з екрана.

8. Дикань, В.Л. Скоростное движение железнодорожного транспорта в мире и перспективы развития в Украине [Текст] / В.Л. Дикань, И.В. Корнилова // Вісник економіки транспорту та промисловості. - 2010. - № 32. - С. 15-25. 


\section{Експлуатація залізниць}

9. Чупир, О.М. Проблеми та нові принципи функціонування будівельної сфери залізничного транспорту України [Електронний ресурс]. - Режим доступу: http://www.economy.nayka.com.ua/ ?op $=1 \& z=1264$. - Назва з екрана.

10. Официальный сайт РЖД [Электронный ресурс]. - Режим доступа: http://annrep.rzd.ru/reports/public/ru?STRUCTURE_ID=4248. - Загл. с экрана.

11. Довідник основних показників роботи залізниць України (2003-2013 роки) [Текст] /- К.: Мін-во трансп. та зв'язку України, Укрзалізниця, 2014. - 42 с.

12. Офіційний сайт Державного комітету статистики України [Електронний ресурс]. - Режим доступу: www.ukrstat.gov.ua/. - Назва з екрана.

Дикань Володимир Леонідович, д-р екон. наук, професор кафедри економіки та управління виробничим i комерційним бізнесом, Український державний університет залізничного транспорту. Тел.: (057) 730-10-96. Корінь Мирослава Василівна, канд. екон. наук, старший викладач кафедри економіки та управління виробничим і комерційним бізнесом, Український державний університет залізничного транспорту. Тел.: (057) 730-10-96. E-mail: miraslava87@mail.ru.

Dykan Volodymyr Leonidovich, doct. of econ. sciences, professor of economics and management of industrial and commercial businesses Ukrainian State University of Railway Transport. Тел.: (057) 730-10-96.

Korin Myroslava Vasylivna, cand. of econ. sciences, senior viladas of economics and management of industrial and commercial businesses Ukrainian State University of Railway Transport. Тел.: (057) 730-10-96. E-mail: miraslava87@mail.ru.

Наукова праця здана до друку 07.07.2015 року 